\title{
Total Plate Count Analysis Of Tuna Fish Adulterated With Lard In Order To Improve Halal Products
}

\section{Analisis Total Mikroba Ikan Tuna Yang Diadulterasi Dengan Lemak Babi Dalam Rangka Meningkatkan Produk Halal}

\author{
Muhammad Taufik13*), Desi Ardilla2), Andro Ghozal2), Mariany Razali33), Maya Handayana Sinaga4) \\ 1)Prodi Kimia, Fakultas Matematika dan IImu Pengetahuan Alam, Universitas Sumatera Utara 20155 \\ 2)Prodi Teknologi Hasil Pertanian, Universitas Muhammadiyah Sumatera Utara, Medan. 20238 \\ 3)Prodi Farmasi, Fakultas Farmasi, Universitas Tjut Nyak Dhien Medan, 20123 \\ 4) Jurusan Farmasi, Poltekes Kemenkes Medan, Jl. Airlangga No. 20 Medan, 20152 \\ *e-mail : muhammad.taufik@usu.ac.id
}

\begin{abstract}
Indonesia is the country with the largest level of Muslim population in the world. Guarantees for the safety and protection of consumers in the food sector must be considered. One of the parameters used in product halal is total microbial analysis. The sample used was processed tuna which is adulterated with lard (1:1). The research method uses Factorial Completely Randomized Design method which consists of two factors, Factor I: Solvent Concentration (K) consists of 4 levels, namely: $\mathrm{K}_{1}=20 \%, \mathrm{~K}_{2}=30 \%, \mathrm{~K}_{3}=40 \%, \mathrm{~K}_{4}=50 \%$, Factors II: Maseration Time (W) consists of 4 levels : $W_{1}=06$ Hours, $W_{2}=12$ Hours, $W_{3}=18$ Hours, and $W_{4}=24$ Hours. The results showed that the $n$-hexane concentration had a very significant effect $(p<0.01)$ on the total microbial parameters. The highest total microbes were in the $50 \%\left(\mathrm{~K}_{4}\right)$ concentration of 4,337 $\log$ CFU / $\mathrm{ml}\left(2.2 \times 104\right.$ CFU / ml) and the lowest value was in the treatment concentration of $20 \%\left(\mathrm{~K}_{1}\right)$ which was 4,216 log CFU / $\mathrm{ml}(1.7 \times 104 \mathrm{CFU} / \mathrm{ml})$. The average microbial total value in the treatment of solvent concentration (K) obtained was 2.0x104 CFU / ml. The treatment of maceration time also gave a very significant effect $(p<0.01)$ on the total microbial parameters. The highest total microbial was 24 hours treatment $=4,410 \log$ CFU $/ \mathrm{ml}(2,6 \times 104 \mathrm{CFU} / \mathrm{ml})$ and the lowest value was at 6 hours treatment which was 4,173 log CFU / ml (1.5x104 CFU / ml). Total microbial analysis provides information on adulteration of lard in processed food products in support of halal certification.
\end{abstract}

Keywords: Total microbes; Halal; h-Hexane; Adulteration; Lard.

\begin{abstract}
ABSTRAK
Indonesia merupakan Negara dengan tingkat populasi Muslim terbesar di dunia Jaminan akan keamanan dan perlindungan konsumen dalam bidang pangan harus sangat diperhatikan. Salah satu parameter yang digunakan dalam kehalalan produk adalah Analisis total mikroba. Sampel yang digunakan adalah ikan tuna olahan yang diadulterasi dengan lemak babi (1: 1). Metode penelitian menggunakan metode Rancangan Acak Lengkap Factorial yang terdiri dari dua faktor yaitu : Faktor I : Konsentrasi Pelarut (K) terdiri dari 4 taraf yaitu: $\mathrm{K}_{1}=20 \%, \mathrm{~K}_{2}=30 \%, \mathrm{~K}_{3}=40 \%, \mathrm{~K}_{4}=50 \%$, Faktor II : Waktu Maserasi (W) terdiri dari 4 taraf yaitu $: W_{1}=06 \mathrm{Jam}, W_{2}=12 \mathrm{Jam}, W_{3}=18 \mathrm{Jam}$, dan $W_{4}=24 \mathrm{Jam}$.
\end{abstract}


Hasil Penelitian menunjukkan bahwa konsentrasi n-heksan memberikan pengaruh yang berbeda sangat nyata $(p<0,01)$ terhadap parameter total mikroba. Total mikroba tertinggi berada pada perlakuan konsentrasi 50\% (K4) yakni 4,337 log CFU/ml (2,2×104 CFU/ml) dan nilai terendah berada pada perlakuan konsentrasi 20\% (K1) yakni 4,216 log CFU/ml (1,7x104 CFU/ml). Nilai rata-rata total mikroba pada perlakuan konsentrasi pelarut (K) yang diperoleh yaitu 2,0x104 CFU/ml. Perlakuan waktu maserasi juga memberikan pengaruh yang berbeda sangat nyata $(p<0,01)$ terhadap parameter total mikroba. Total mikroba tertinggi berada pada perlakuan 24 jam yaitu 4,410 log CFU/ml $(2,6 \times 104 \mathrm{CFU} / \mathrm{ml})$ dan nilai terendah berada pada perlakuan 6 jam yakni sebesar $4,173 \mathrm{log}$ CFU/ml $(1,5 \times 104 \mathrm{CFU} / \mathrm{ml})$.Analisis Total mikroba memberikan informasi adulterasi lemak babi dalam produk pangan olahan dalam mendukung sertifikasi halal.

Kata kunci: Total mikroba; Halal; h-Heksan; Adulterasi; Lemak babi.

\section{PENDAHULUAN}

Pada saat sekarang ini, konsumen semakin selektif dalam mengkonsumsi bahan makanan (Burlian, 2013). Meningkatnya tingkat kesadaran konsumen tentang pola hidup yang sehat dan meningkatnya daya beli konsumen membuat konsumen tidak asal memilih dalam menentukan bahan pangan terutama bahan pangan halal (Hilda \& Si, 2014). Selain itu, perubahan gaya hidup khususnya bagi masyarakat perkotaan yang semakin sibuk menjadikan produk pangan yang cepat dan praktis menjadi pilihan. Salah satunya adalah produk makanan kaleng seperti produk ikan tuna kaleng(Ahmed, Haq, Cho, \& Chun, 2017). Konsumsi masyarakat dunia terhadap tuna kaleng sangat besar. Konsumsi tuna kaleng (Tahun 2016) mencapai 200 juta karton dan umumnya satu karton tuna kaleng terdiri dari 48 kaleng tuna (Mala Nurilmala, Agoes Mardiono Jacoeb, 2017).

Indonesia merupakan Negara dengan tingkat populasi Muslim terbesar di dunia (Ardilla et al., 2018). Jaminan akan keamanan dan perlindungan konsumen dalam bidang pangan harus sangat diperhatikan (Faridah Jalil, 2014). Total jumlah penduduk Indonesia tahun 2018 yang mencapai 270 juta jiwa, sekitar 209,28 juta jiwa penduduk Indonesia merupakan pemeluk agama Islam. Berdasarkan data tersebut, maka dalam hal keamanan pangan tentu masyarakat Indonesia khususnya Muslim harus memiliki jaminan bahwa produk yang dikonsumsi adalah makanan yang halal dan baik (Taufik et al., 2018).

Keamanan pangan bagi konsumen telah diatur oleh pemerintah dalam Undang-Undang
Nomor 18 Tahun 2012 tentang pangan. Keamanan pangan diselenggarakan untuk menjaga pangan tetap aman, higienis, bermutu, bergizi dan tidak bertentangan dengan agama, keyakinan dan budaya masyarakat.Namun, jaminan produk halal menjadi sangat penting mengingat adanya kemajuan ilmu pengetahuan dan teknologi dibidang pangan yang berkembang pesat. Hal ini berpengaruh secara nyata pada pergeseran pengolahan dan pemanfaataan bahan baku untuk produk makanan (Gustiani, 2009) (Hilda \& Si, 2014). Selain itu keaslian bahan makanan berhubungan dengan kesehatan manusia karena bahannya bisa saja bersifat zat alergenik atau toksik (Fadzlillah, Man, \& Jamaludin, 2011).

Pencampuran bahan yang tidak diinginkan dalam suatu produk tertentu secara sengaja disebut adulterasi (Food, 2017). Masalah yang berkaitan dengan adanya unsur babi beberapa kali pernah terjadi di Indonesia. Sebagai contoh yaitu produk Monosodium Glutamate (MSG) yang dalam proses produksinya menggunakan katalis dari Bactosoytone yang mengandung enzim babi. Enzim babi tidak terdeteksi pada produk akhir MSG, namun karena adanya pemanfaatan zat haram dalam proses produksi. Berdasarkan temuan tersebut, sertifikat halal dari Lembaga Pengkajian Pangan, Obat dan Kosmetika Majelis Ulama Indonesia (LPPOM MUI) dicabut dan produsen harus menarik seluruh produk yang telah beredar di seluruh Indonesia. Setelah melalui proses sertifikasi ulang dengan mengganti katalis enzim babi menjadi enzim sapi, produk ini dinyatakan halal dan beredar di masyarakat sampai sekarang. Selain itu kasus lainnya yaitu 
yang ditemukan baru-baru ini, BPOM meminta penarikan produk mie asal korea karena mengandung fragmen DNA babi. Produk mie itu di antaranya Samyang (mie instan U-Dong), Samyang (mie instan rasa Kimchi), Nongshim dan Ottogi mie instant Yeul Ramen (Fadzlillah et al., 2011)(A.N. Nina Naquiah, J.M.N. Marikkar*, M.E.S. Mirghani, 2017) (Taufik, Ardila, Razali, \& Alfian, 2019).

Tantangan dalam menentukan keaslian makanan memang semakin meningkat untuk analis makanan karena praktek pemalsuan menjadi lebih halus dan rumit, sehingga untuk mendeteksi menjadi sangat sulit (A.N. Nina Naquiah, J.M.N. Marikkar*, M.E.S. Mirghani, 2017). Upaya melakukan identifikasi telah dilakukan dengan berbagai metode. Metode yang telah berkembang adalah metode deteksi dengan Fourier Transform Infra Red (FTIR) untuk mendeteksi kandungan lemak babi akan tetapi preparasi sampel yang tidak mudah (Rohman, Triyana, Sismindari, \& Erwanto, 2012) (Erwanto, Y., Rohman, A., Arsyanti, L. and Pranoto, 2018). Identifikasi lainnya dengan metode PCR-RFLP gen cytocrome $b$ dan PCR primer spesifik gen amilogenin (Samac, Margeta, \& Vincek, 2017). Kelemahan dalam metode PCR-RFLP adalah membutuhkan waktu yang panjang karena melalui dua tahap analisis penting yaitu PCR itu sendiri dan pemotongan DNA hasil PCR dengan enzim restriksi.Uji total mikroba pada sosis sapi telah dilakukan dan Hasil analisis terhadap total mikroba menunjukkan bahwa konsentrasi nheksana pada sosis sapi : lemak babi (1: 1) memberikan pengaruh yang berbeda sangat nyata $(P>0,01)$. Jumlahmikroba tertinggi terdapat pada $\mathrm{K}_{1}(9487,500)$ dan terendah pada $\mathrm{K}_{4}$ $(3887,500)$ (Razali, Siregar, Sari, \& Sinaga, 2018).

Tingkat kontaminasi daging ikan tuna oleh mikroba dipengaruhi oleh kondisi lingkungan, metode penangkapan ikan, penanganan, pengolahan dan evisceration (pengeluaran isi perut). Tetapi dengan tertundanya penanganan di atas kapal dan pendinginan ikan selama penyimpanan serta pengiriman ke pasar dan pabrik pengolahan, daging mudah sekali mengalami kerusakan oleh mikroba (Casalinuovo et al., 2015). Penelitian ini bertujuan untuk menganalisis total mikroba ikan tuna yang diadulterasi dengan lemak babi dalam rangka meningkatkan produk pangan halal. Manfaat penelitian adalah untuk memberikan informasi secara akurat jumlah total mikroba produk pangan yang diadulterasikan dengan lemak babi.

\section{METODE PENELITIAN}

\section{Tempat dan Waktu Penelitian}

Penelitian ini dilakukan di Laboratorium Teknologi Hasil Pertanian Fakultas Pertanian Universitas Muhammadiyah Sumatera Utara pada bulan Januari s/d Agustus 2018.

\section{Bahan dan alat Penelitian}

Bahan-bahan yang digunakan dalam penelitian ini adalah produk tuna kaleng dan lemak babi. Bahan kimia yang digunakan dalam penelitian ini adalah n-Heksana, Nutrient Agar, Kloroform, Alkohol 96\%, dan $\mathrm{Na}_{2} \mathrm{SO}_{4}$.

Peralatan yang digunakan Adalah Erlenmeyer, Beaker Glass, Pipet Tetes, Pipet Ukur, Gelas Ukur, Kaca Arloji, Neraca Analitik, Pisau, Sarung Tangan, Tabung Reaksi, Desikator, Inkubator, Autoklaf, Colony Counter, Kertas saring dan Petridish.

\section{Metode Penelitian}

Metode penelitian dilakukan dengan metode Rancangan Acak Lengkap Factorial yang terdiri dari dua faktor yaitu : Faktor I : Konsentrasi Pelarut $(\mathrm{K})$ terdiri dari 4 taraf yaitu: $\mathrm{K}_{1}=20 \%, \mathrm{~K}_{2}=$ $30 \%, \mathrm{~K}_{3}=40 \%, \mathrm{~K}_{4}=50 \%$, Faktor II : Waktu Maserasi (W) terdiri dari 4 taraf yaitu $: W_{1}=06$ Jam, $W_{2}=12 \mathrm{Jam}, W_{3}=18 \mathrm{Jam}$, dan $W_{4}=24 \mathrm{Jam}$.

\section{Preparasi Sampel}

Sampel yang akan diuji adalah produk tuna olahan murni dan produk tuna olahan yang bercampur dengan lemak babi (1: 1).

\section{Ekstraksi sampel}

1. Sampel ikan tuna kaleng ditimbang 5 gram, kemudian bahan dihaluskan.

2. Ditambahkan lemak babi sebanyak 5 gram, diaduk.

3. Dimaserasi dengan pelarut $n$-heksan sesuai perlakuan penelitian(Taufik et al., 2018)

4. Disaring dengan menggunakan kain flanel

5. Disaring kembali dengan kertas saring yang telah diberi $\mathrm{Na}_{2} \mathrm{SO}_{4}$ anhidrat

6. Di uji total mikroba 


\section{Uji Total Mikroba (Total Plate Count)}

- Semua peralatan disterilkan dengan menggunakan autoklaf pada tekanan 15 psi selama 15 menit pada suhu $121^{\circ} \mathrm{C}$. Ditimbang NA (Nutrient Agar) dan masukkan ke dalam Erlenmeyer dan diberi Aquades sebanyak 250 $\mathrm{ml}$, kemudian dihomogenkan dengan Magnetic Stirer selanjutnya direbus sampai larut dan disterilkan dengan autoclave pada tekanan 15 psi dengan suhu $121^{\circ} \mathrm{C}$ selama 15 menit.

- Larutan pengencer $0,9 \% \mathrm{NaCl}$ disiapkan masing-masing pengenceran tingkat pertama $90 \mathrm{ml}$ dan mulut Erlenmeyer ditutupi alumunium foil, sedangkan untuk tingkat pengenceran kedua dan ketiga masing-masing diambil $9 \mathrm{ml} \mathrm{NaCl}$ 0,9\% kemudian dimasukkan ke dalam tabung hush yang dilengkapi dengan penutup. Semua larutan pengenceran disterilkan dengan autoclave dengan suhu $121^{\circ} \mathrm{C}$ tekanan 15 psi selama 15 menit. Sampel ditimbang 10 gram secara aseptis kemudian dimasukkan ke dalam $90 \mathrm{ml} \mathrm{NaCl}$ $0,9 \%$ steril sehingga diperoleh larutan dengan tingkat pengenceran 10-1. Dari pengenceran 10-1 dipipet $1 \mathrm{ml}$ ke dalam tabung reaksi 2, kemudian homogenkan sehingga diperoleh pengenceran 10-2. Dari setiap pengenceran diambil $1 \mathrm{ml}$ pindahkan ke cawan petri steril yang telah diberi kode untuk tiap sampel pada tingkat pengenceran tertentu.

- Ke dalam semua cawan petri dituangkan secara aseptis NA sebanyak $15-20 \mathrm{ml}$. Setelah penuangan, cawan petri digoyang perlahan-lahan sambil diputar 3 kali ke kiri, ke kanan, lalu ke depan, ke belakang, kiri dan kanan, kemudian didinginkan sampai agar mengeras. Setelah NA padat dimasukkan ke dalam inkubator selama 24 jam pada suhu $37^{\circ} \mathrm{C}$. Setelah masa inkubasi berakhir, dilakukan perhitungan jumlah bakteri dan jumlah bakteri dikalikan dengan 1 per pengenceran. Perhitungan jumlah koloni menggunakan rumus sebagai berikut:

Total Bakteri = Jumlah Koloni Bakteri x 1/ Pengenceran

\section{HASIL DAN DISKUSI}

Pengaruh Konsentrasi n-Heksan dapat dianalisis sebagai berikut:

Daftar sidik ragam (Tabel 1a dan 1b) menunjukkan bahwa konsentrasi n-heksan memberikan pengaruh yang berbeda sangat nyata $(p<0,01)$ terhadap parameter total mikroba. Tingkat perbedaan tersebut telah diuji dengan uji beda rata-rata dan dapat dilihat pada Tabel 2.

Tabel 2 menunjukkan jumlah total bakteri mengalami peningkatan seiring dengan besarnya konsentrasi pelarut. Perlakuan $\mathrm{K}_{1}$ memberikan pengaruh yang berbeda sangat nyata dengan perlakuan $\mathrm{K}_{2}, \mathrm{~K}_{3}$ dan $\mathrm{K}_{4}$. Perlakuan $\mathrm{K}_{2}$ berbeda tidak nyata dengan perlakuan $\mathrm{K}_{3}$, namun berbeda sangat nyata dengan perlakuan $\mathrm{K}_{4}$. Perlakuan $\mathrm{K}_{3}$ berbeda tidak nyata dengan perlakuan $\mathrm{K}_{4}$. Total mikroba terendah antar perlakuan konsentrasi pelarut berada pada perlakuan $\mathrm{K}_{1}$ yakni 4,216 log CFU/ml (1,7x104 CFU/ml) dan nilai tertinggi pada perlakuan $\mathrm{K}_{4}$ yakni 4,337 log CFU/ml (2,2×104 CFU/ml). Nilai tersebut dapat dilihat pada Gambar 1.

Gambar 1 menunjukkan bahwa total mikroba yang dihasilkan dari perlakuan $20 \%$ sampai ke perlakuan $50 \%$ terus mengalami peningkatan. Pada konsentrasi $20 \%$ total mikroba berada pada 4,216 log CFU/ml (1,7x104 CFU/ml), kemudian terus terjadi kenaikan sampai titik tertinggi yaitu pada konsentrasi $50 \%$ menjadi 2,2x104 CFU/ml dan jika dirata-ratakan yaitu 2x104 CFU/ml..

Hasil penelitian menunjukkan bahwa total mikroba dari produk tuna murni yaitu $1,1 \times 104$ $\mathrm{CFU} / \mathrm{ml}$. Sedangkan pada produk yang bercampur lemak babi naik menjadi 2x104 CFU/ml. Banyak faktor yang mempengaruhi pertumbuhan dari mikroba seperti kandungan gizi pada substrat, kadar air, suhu, kelembaban dan derajat keasaman. Meningkatnya jumlah total mikroba pada produk bercampur lemak babi disebabkan oleh kandungan gizi yang terkandung pada substrat yang juga semakin meningkat. Hal ini disebabkan karena pada saat konsentrasi pelarut lebih banyak, maka pelarut akan semakin lama mencapai titik jenuh sehingga lebih banyak kandungan substrat yang terekstrak dalam minyak. Ikan tuna memiliki kandungan lemak yaitu $4-5 \%$ yang didominasi oleh lemak tidak jenuh. Kandungan lemak babi berkisar sekitar 20,24\%(Hilda \& Si, 2014). Dengan tingginya lemak pada babi, maka bakteri yang bersifat lipolitik akan semakin meningkat jumlahnya akibat substrat yang sangat sesuai bagi perkembangan dan pertumbuhannya. berikut :

Pengaruh Waktu Maserasi adalah sebagai 
Tabel 1.a. Rataan Total Mikroba Produk Tuna Bercampur Babi (Log CFU/ml) memberikan pengaruh yang berbeda tidak nyata dengan perlakuan $\mathrm{W}_{2}$ dan berbeda sangat nyata dengan perlakuan $W_{3}$ dan $W_{4}$. Perlakuan $W_{2}$ berbeda sangat nyata dengan perlakuan $\mathrm{W}_{3}$ dan $W_{4}$. Perlakuan $W_{3}$ berbeda tidak nyata dengan perlakuan $W_{4}$. Total mikroba terendah antar perlakuan waktu maserasi berada pada perlakuan W1 yakni 4,173 log CFU/ml (1,5x104 CFU/ml) dan nilai tertinggi pada perlakuan W4 yakni 4,410 $\log \mathrm{CFU} / \mathrm{ml}$ (2,6x104 CFU/ml). Hasil tersebut dapat dilihat pada Gambar 2.

Gambar 2 menunjukkan bahwa total mikroba yang dihasilkan dari perlakuan 6 jam sampai ke perlakuan 24 jam terus mengalami peningkatan. Pada lama maserasi 6 jam total mikroba berada pada 4,173 log CFU/ml (1,5x104 $\mathrm{CFU} / \mathrm{ml})$. Kemudian terus terjadi kenaikan sampai titik tertinggi yaitu pada waktu maserasi 24 jam menjadi 4,410 log CFU/ml (2,6x104 CFU/ml). Hal ini menunjukkan bahwa jumlah total mikroba yang diperoleh berkisar antara 4,173 log CFU/ml sampai 4,410 log CFU/ml dengan nilai rata-rata (2x104 CFU/ml). Gambar 3 sampai dengan Gambar 7 menunjukkan proses pengerjaan di Taboratorium. Pengujian Total Mikroba merupakan salah satu parameter yang digunakan dalam pengujian kehalalan suatu produk pangan. Jumlah Total mikroba lemak babi akan memiliki hasil yang berbeda dengan lemak dari hewan lain (ikan tuna). Perbedaan yang signifikan ini menyebabkan timbulnya karakteristik tersendiri dalam menganalisis lemak babi yang teradulterasi dalam produk pangan yang beredar di Masyarakat. mengalami peningkatan seiring dengan bertambahnya waktu maserasi. Perlakuan $W_{1}$

Tabel 1 b. Analisis Sidik Ragam Total Mikroba Produk Tuna Bercampur Babi

\begin{tabular}{llllllll}
\hline SK & $\mathrm{db}$ & $\mathrm{JK}$ & $\mathrm{KT}$ & $\mathrm{F} \mathrm{hit.}$ & & 0,05 & 0,01 \\
\hline Perlakuan & 15 & 0,404 & 0,027 & 20,981 & $* *$ & 2,35 & 3,41 \\
W & 3 & 0,319 & 0,106 & 82,743 & $* *$ & 3,24 & 5,29 \\
W Lin & 1 & 0,298 & 0,298 & 232,464 & $* *$ & 4,49 & 8,53 \\
W kuad & 1 & 0,00062 & 0,00062 & 0,490 & th & 4,49 & 8,53 \\
K & 3 & 0,067 & 0,022 & 17,529 & $* *$ & 3,24 & 5,29 \\
K Lin & 1 & 0,064 & 0,064 & 49,788 & $* *$ & 4,49 & 8,53 \\
K Kuad & 1 & 0,00353 & 0,00353 & 2,7514 & $* *$ & 4,49 & 8,53 \\
WxK & 9 & 0,018 & 0,002 & 1,545 & tn & 2,54 & 3,78 \\
\hline Galat & 16 & 0,021 & 0,001 & & & & \\
\hline Total & 31 & 0,424 & 0,0136 & & & & \\
\hline
\end{tabular}


Keterangan :

$\begin{array}{ll}\text { FK } & : 588,066 \\ \text { KK } & : 0,836 \% \\ * * & : \text { Sangat Nyata } \\ \text { tn } & : \text { Tidak Nyata }\end{array}$

Tabel 2.Hasil Uji Beda Rata-Rata Pengaruh Konsentrasi n-Heksan Terhadap Parameter Total Mikroba Produk Tuna Kaleng Bercampur Lemak Babi

\begin{tabular}{cccccccc}
\hline \multirow{2}{*}{ Jarak } & \multicolumn{2}{c}{ LSR } & Perlakuan & Rataan & \multicolumn{2}{c}{ Notasi } \\
\cline { 2 - 5 } \cline { 7 - 8 } & 0.05 & 0.01 & & $\mathrm{~K}(\%)$ & $(\log$ CFU/ml) & 0,05 & 0,01 \\
\hline- & - & - & & $\mathrm{K}_{1}=20$ & 4,216 & $\mathrm{C}$ & $\mathrm{C}$ \\
2 & 0,038 & 0,052 & & $\mathrm{~K}_{2}=30$ & 4,279 & $\mathrm{~b}$ & $\mathrm{~B}$ \\
3 & 0,040 & 0,055 & & $\mathrm{~K}_{3}=40$ & 4,315 & $\mathrm{ab}$ & $\mathrm{AB}$ \\
4 & 0,041 & 0,056 & & $\mathrm{~K}_{4}=50$ & 4,337 & $\mathrm{a}$ & $\mathrm{A}$ \\
\hline
\end{tabular}

Keterangan: Huruf yang berbeda pada kolom notasi menunjukkan pengaruh yang berbeda nyata pada taraf $5 \%$ dan berbeda sangat nyata pada taraf $1 \%$.

Tabel 3. Hasil Uji Beda Rata-Rata Pengaruh Waktu Maserasi pada Parameter Total Mikroba.Produk Tuna Kaleng Bercampur Lemak Babi

\begin{tabular}{ccclcccc}
\hline \multirow{2}{*}{ Jarak } & \multicolumn{2}{c}{ LSR } & & Perlakuan & Rataan & \multicolumn{2}{c}{ Notasi } \\
\cline { 2 - 3 } \cline { 7 - 8 } & 0,05 & 0,01 & & W (Jam) & $(\log$ CFU/ml) & 0,05 & 0,01 \\
\hline- & - & - & $\mathrm{W}_{1}=6$ & 4,173 & $\mathrm{C}$ & $\mathrm{B}$ \\
2 & 0,038 & 0,052 & & $\mathrm{~W}_{2}=12$ & 4,206 & $\mathrm{C}$ & $\mathrm{B}$ \\
3 & 0,040 & 0,055 & & $\mathrm{~W}_{3}=18$ & 4,359 & $\mathrm{~b}$ & $\mathrm{~A}$ \\
4 & 0,041 & 0,056 & & $\mathrm{~W}_{4}=24$ & 4,410 & $\mathrm{a}$ & $\mathrm{A}$ \\
\hline
\end{tabular}

Keterangan: Huruf yang berbeda pada kolom notasi menunjukkan pengaruh yang berbeda nyata pada taraf $5 \%$ dan berbeda sangat nyata pada taraf $1 \%$.

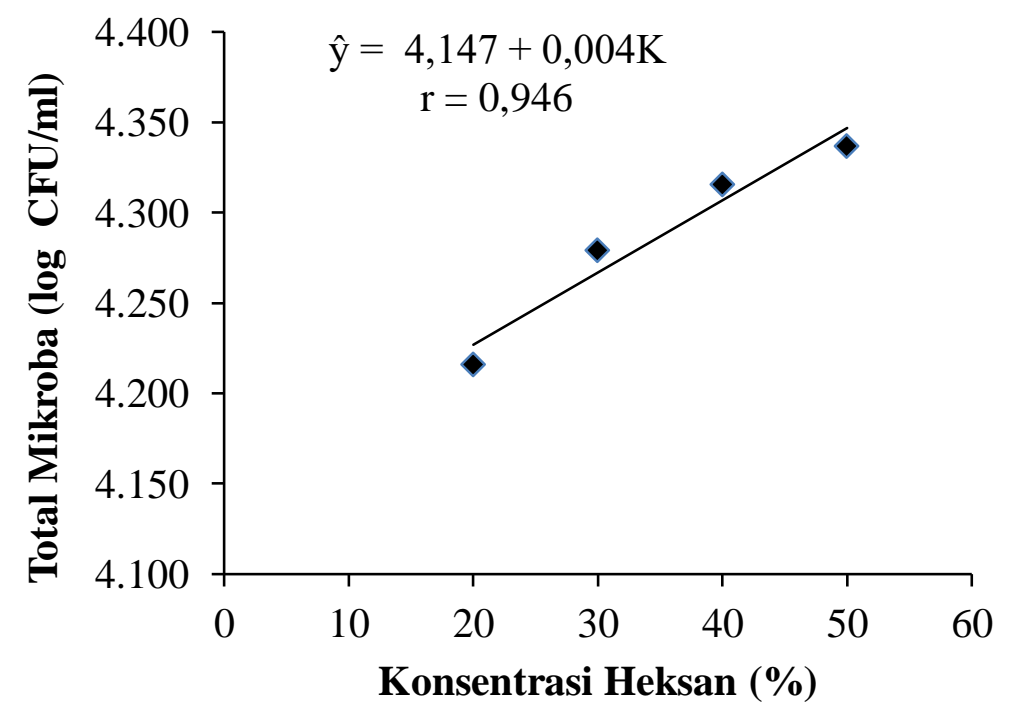

Gambar 1. Pengaruh Konsentrasi n-Heksan terhadap Total Mikroba Produk Tuna Kaleng Bercampur Lemak Babi 


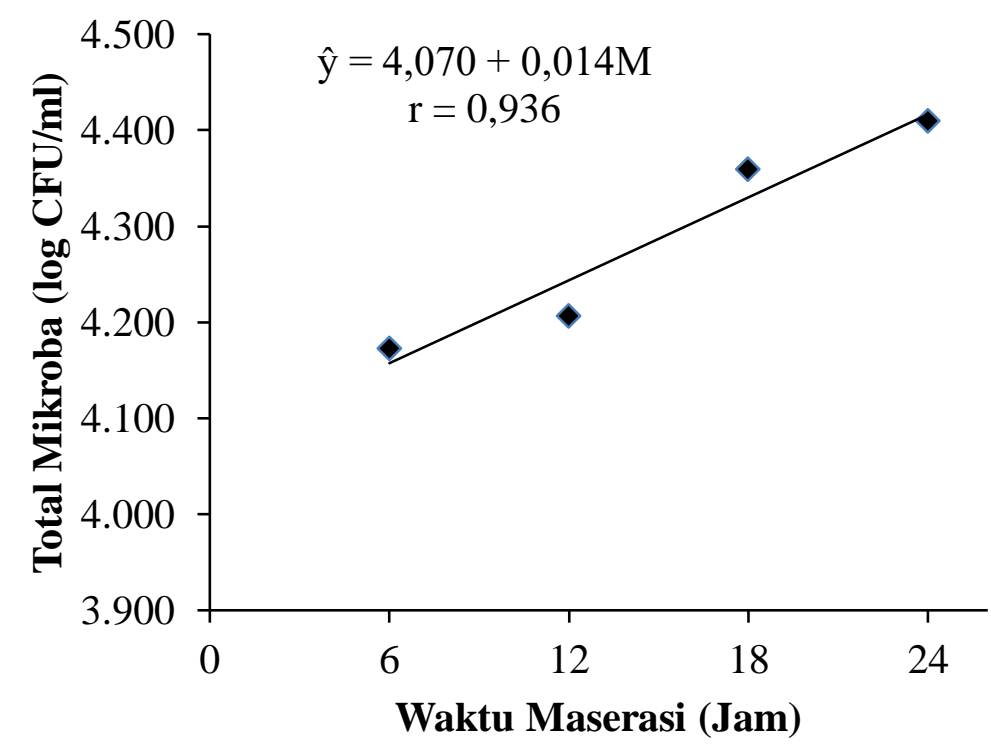

Gambar 2. Pengaruh Waktu Maserasi terhadap Total Mikroba Produk Tuna Kaleng Bercampur Lemak Babi

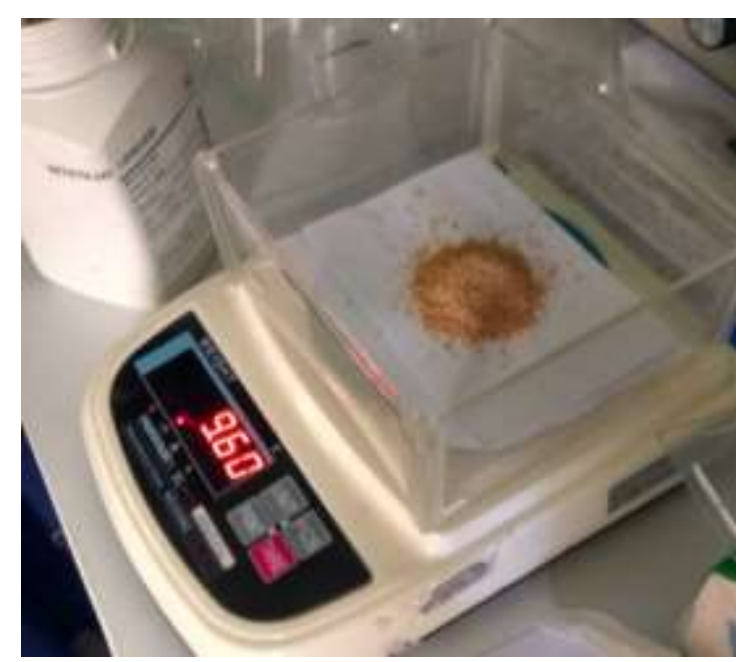

Gambar 3.Penimbangan Nutrient Agar

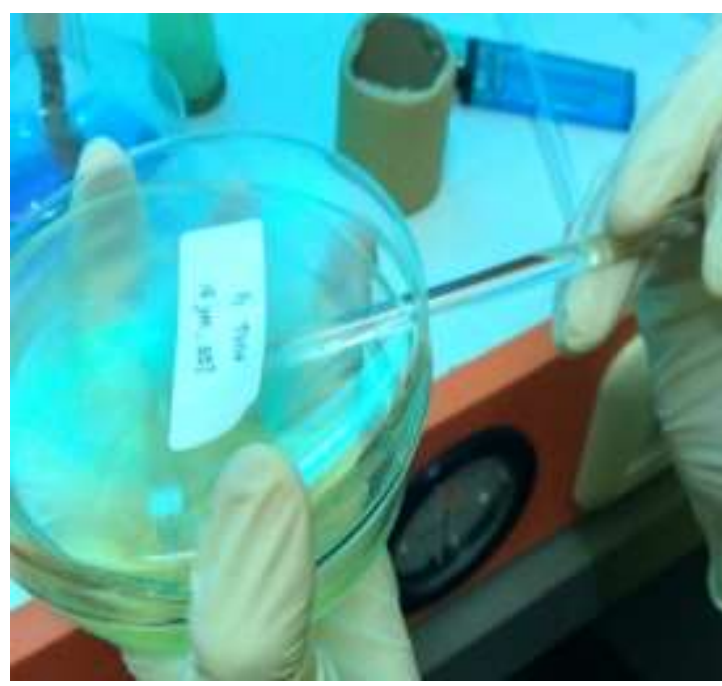

Gambar 5.Penanaman Sampel pada Nutrient Agar

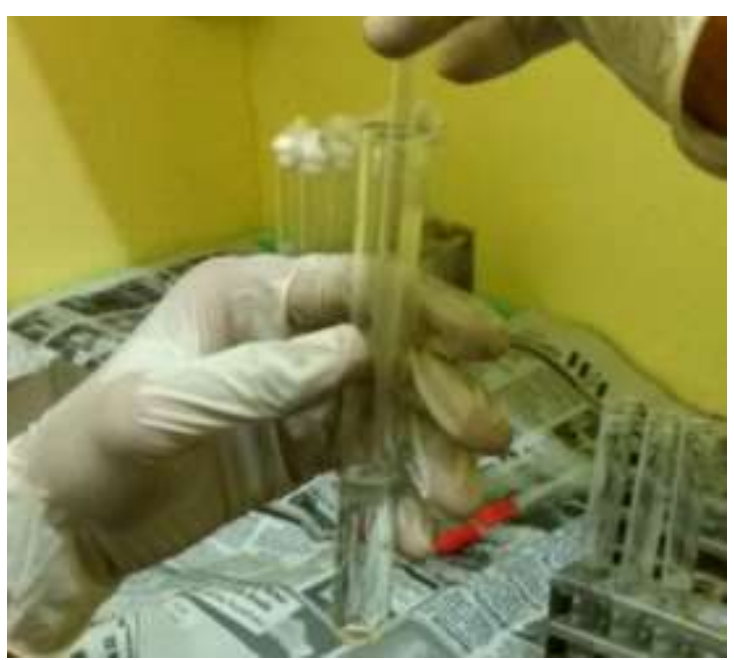

Gambar 4. Proses Pengenceran

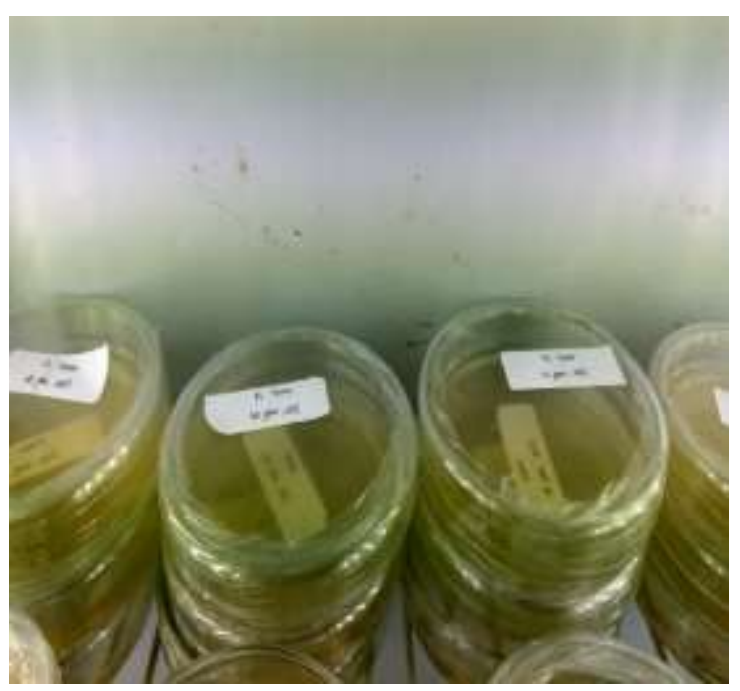

Gambar 6. Inkubasi selama 24 jam dalam Inkubator 


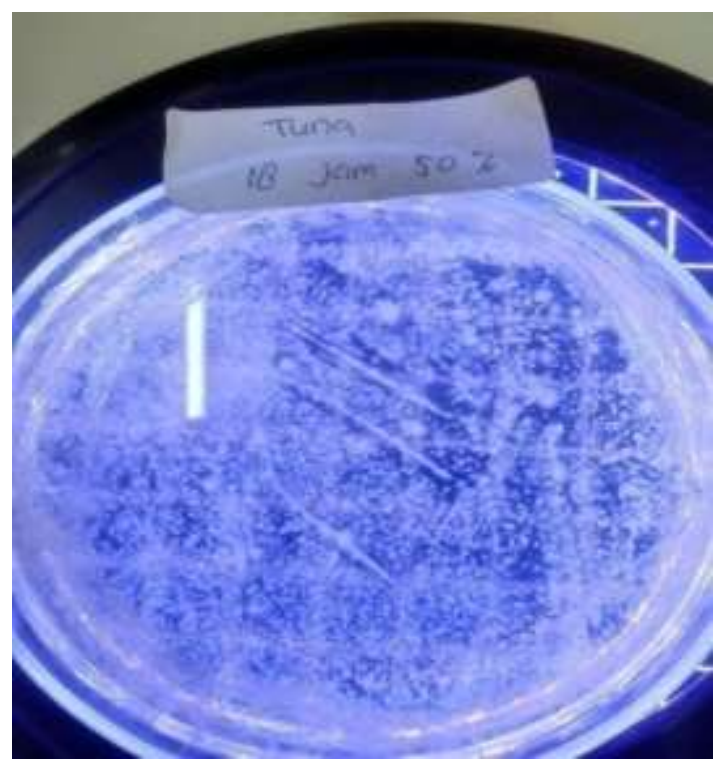

Gambar 7. Mikroba pada Lemak Tuna + Lemak Babi (1: 1)

\section{KESIMPULAN}

1. Konsentrasi pelarut memberikan pengaruh yang berbeda sangat nyata $(p<0,01)$ terhadap total mikroba.Waktu maserasi memberikan pengaruh yang sangat nyata $(p<0,01)$ pada analisis total mikroba.Konsentrasi pelarut memberikan pengaruh yang berbeda sangat nyata $(p<0,01)$ terhadap analisis total mikroba.

2. Analisis Total mikroba memberikan informasi adulterasi lemak babi dalam produk pangan olahan dalam mendukung sertifikasi halal.

\section{UCAPAN TERIMAKASIH}

Ucapan terima kasih kepada Kemenristekdikti melalui dana DRPM Tahun 2018 yang telah mendukung penelitian ini.

\section{REFERENSI}

a.N. Nina Naquiah, J.M.N. Marikkar*, M.E.S. Mirghani, A. F. N. \& N. A. M. Y. (2017). Differentiation of Fractionated Components of Lard from Other Animal Fats Using Different Analytical Techniques. Sains Malaysiana, 46(2), 209-216.

Ahmed, R., Haq, M., Cho, Y., \& Chun, B. (2017). Quality Evaluation of Oil Recovered from Byproducts of Bigeye Tuna Using Supercritical Carbon Dioxide Extraction. Turkish Journal of Fisheries and Aquatic Sciences, 672, 663-672. https://doi.org/10.4194/1303-2712v17

Ardilla, D., Taufik, M., Tarigan, D. M., Thamrin,
M., Razali, M., \& Siregar, H. S. (2018). Analisis Lemak Babi Pada Produk Pangan Olahan Menggunakan Spektroskopi UV Vis Analysis Of Lard In The Meat Processed Using UV - Vis Spectroscopy. AGRINTECH - Jurnal Teknologi Pangan \& Hasil Pertanian, 1(2), 111-116.

Burlian, P. (2013). Reformulasi Yuridis Pengaturan Produk Pangan Halal. Ahkam, XIV(November), 43-52.

Casalinuovo, F., Gazzotti, T., Rippa, P., Ciambrone, L., Musarella, R., Pratticò, E., \& Bo, E. (2015). Microbiological stability of canned tuna produced in Italy and in nonEuropean countries. Italian Journal of Food Safety, 4, 4-7. https://doi.org/10.4081/ijfs.2015.4780

Erwanto, Y., Rohman, A., Arsyanti, L. and Pranoto, Y. (2018). Identification of pig DNA in food products using polymerase chain reaction ( PCR ) for halal authentication-a review. International Food Research Journal, 25(August), 1322-1331.

Fadzlillah, N. A., Man, Y. B. C., \& Jamaludin, M. A. (2011). Halal Food Issues from Islamic and Modern Science Perspectives. In 2011 2nd International Conference on Humanities, Historical and Social Sciences IPEDR vol.17 (2011).

Faridah Jalil, N. M. (2014). Administration and Enforcement of Halal Certification in Malaysia - a Possibility towards Cooperative Federalism. MIHREC, (September 2015). 
Fazial, F. F., Ling, T. L., Al, A., Ahmad, A., \& Zubairi, S. I. (2017). Physicochemical Characterization of Biofluid Metabolites from Liquid Residual of Tuna Fish ( Euthynnus affinis ) throughout Refrigerated Storage Condition. Journal of Food Quality, 2017, 18.

Food, I. (2017). Analysis of beef meatball adulteration with wild boar meat using realtime polymerase chain reaction. International Food Research Journal, 24(December), 2451-2455.

Gustiani, E. (2009). Pengendalian Cemaran Mikroba Pada Bahan Pangan Asal Ternak (Daging Dan Susu) Mulai Dari Peternakan Sampal Dihidangkan. Jurnal Litbang Pertanian, 28(80), 96-100.

Hilda, L., \& Si, M. (2014). Analisis Kandungan Lemak Babi dalam produk pangan di Padangsidimpuan secara kualitatif dengan menggunakan Gas Kromatografi (GC). Tazkir, 9(Juli-Desember), 1-15.

Mailoa, M. N., Tapotubun, A. M., \& Theodora, E. A. A. (2017). Analysis Total Plate Counte ( TPC) On Fresh Steak Tuna Applications Edible Coating Caulerpa sp During Stored at Chilling Temperature Analysis Total Plate Counte ( TPC ) On Fresh Steak Tuna Applications Edible Coating Caulerpa $\mathrm{sp}$ During Stored at Chilling. IOP Conf. Series: Earth and Environmental Science, 89, 1-7.

Mala Nurilmala *, Agoes Mardiono Jacoeb, R. A. D. (2017). Karekteristik Gelatin Kulit Ikan Tuna Sirip Kuning. JPHPI 2017,20(2013), 339-350.

Razali, M., Siregar, R. T., Sari, N., \& Sinaga, M. H. (2018). Analisis Mikrobiologi Forensik Total Mikroba Sosis Sapi yang Bercampur Lemak Babi dalam Rangka Kehalalan Produk. AGRINTECH - Jurnal Teknologi Pangan \& Hasil Pertanian, 2(1), 33-39.

Rohman, A., Triyana, K., Sismindari, S., \& Erwanto, Y. (2012). Differentiation of lard and other animal fats based on triacylglycerols composition and principal component analysis Fourier Transform Infrared Spectroscopy applied for rapid analysis of lard in palm oil. International Food Research Journal, 19(January), 11611165.

Samac, D., Margeta, V., \& Vincek, D. (2017). Efficiency of PCR-RFLP and Species- specific PCR for the Identification of Meat Origin in Dry Sausages. Czech J. Food Sci, 2017(5), 386-391. https://doi.org/10.17221/243/2016-CJFS

Taufik, M., Ardila, D., Razali, M., \& Alfian, Z. (2019). Investigation of Lard on Pork Nuggets using UV Spectrophotometry. Indian Journal of Science and Technology, 12(January), 10-13. https://doi.org/10.17485/ijst/2019/v12i2/1383 33

Taufik, M., Ardilla, D., Mawar, D., Thamrin, M., Razali, M., \& Afritario, M. I. (2018). Studi Awal : Analisis Sifat Fisika Lemak Babi Hasil Ekstraksi Pada Produk Pangan Olahan. AGRINTECH - Jurnal Teknologi Pangan \& Hasil PertanianJurnal Teknologi Pangan Dan Hasil Pertanian, 1(2), 79-85. 